\title{
Cognitive Skills Development among Transfer College Students: An Analysis by Student Gender and Race
}

\author{
David Edens (corresponding author) \\ Department of Human Nutrition and Food Science, Cal Poly Pomona \\ 3801 West Temple Ave, Pomona, California, 93801, United States \\ Tel: 1-909-869-5226 E-mail: dredens@cpp.edu \\ Heather Dy \\ Life Science Department, Long Beach City College \\ 4901 E. Carson St, Long Beach, California, 90808, United States \\ Tel: 1-562-938-4630 E-mail: hdy@lbcc.edu \\ James Dalske \\ Student Affairs, The California Maritime Academy \\ 200 Maritime Academy Drive, Vallejo, California, 94590, United States \\ Tel: 1-707-654-1070 E-mail: jdalske@csum.edu \\ Cassandra Strain \\ Financial Aid, Northern Arizona University \\ PO Box 6236, Yuma, AZ 85366-6236
}

Tel: 1-928-317-6437 E-mail: cassandra.strain@ nau.edu

Received: Mach 15, 2015 Accepted: April 12, 2015 Published: May 11, 2015

doi:10.5296/jet.v2i2.7227 URL: http://dx.doi.org/10.5296/jet.v2i2.7227

\begin{abstract}
The purpose of the study is to improve the understanding of transfer college students, by examining the patterns in and predictors of cognitive skills development among transfer college students. Moreover, this study examined how such patterns and predictors differ by student's gender and race within this population. Results found that men and women transfer students have differing cognitive skills gains after transferring to a 4-year institution. Results also indicated that there are differences in the cognitive skills gained in college by transfer students from various races. Finally, using regression analysis, models were developed to predict the variance in cognitive skills development for transfer students. Models were able to $33 \%$ and $46 \%$ of the variance in cognitive skills gains, when evaluated by gender or ethnicity.
\end{abstract} Keywords: Cognitive Development, Transfer Students, Transfer Issues 


\section{Introduction}

Transfer students represent a significant portion of the current college student population. One-third of students attending a four-year institution have transferred from either a two-year college or another four-year institution (Marling, 2013). A study conducted by The National Student Clearinghouse Research Center in partnership with the Indiana University Project on Academic Success profiled student transfer pathways by tracking the transfer patterns of 2.8 million students over a five-year period (Chen, Dundar, Hossler, Torres, Shapiro, Ziskin, \& Zerquera, 2012). The study reported that most students (37\%) who transferred from one institution to another did so in their second year, $25 \%$ moved more than once during this five-year period, $27 \%$ transferred across state lines, and $43 \%$ transferred into a public two-year institution. Although our study focuses on transfer students currently attending a four-year institution, studies suggest that no typical transfer pattern exists among college students.

Beyond transfer patterns, additional research has focused on the behaviors supporting transferring from one institution to another. Research on 150,000 California community students revealed the course enrollment patterns and transfer goals of students matriculating into four-year institutions (Research and Planning Group for California Community Colleges, 2010). The project found that students who started their college education taking college-level Math and college-level English courses (25\% and 16\%, respectively) were more apt to transfer. In addition, $75 \%$ of the cohort had indicated a transfer goal at some point during their community college enrollment.

While the percentage of transfer students has increased over the past decade, empirical studies on this population are still sparse in college impact research. In addition, most existing research on transfer students tends to focus on either demographic characteristics of this population (Eimers \& Mullen, 1997) or their successful transition (Cejda, Kaylon, \& Rewey, 1998; Sanchez, Laanan, \& Wiseley, 1999), while relatively ignoring the examination of their actual "development" or "growth" during the college years. Methodologically, most of the studies have also used data from a single institution or small sample sizes (Davies \& Dickmann, 1998; Miville \& Sedlacek, 1995).

Although previous studies have identified particular predictors of cognitive skill development, the data may not be applicable to the transfer student population (Pascarella and Terenzini, 2005; Shim \& Walczak, 2012). Several gaps in the current literature remain: (1) There are few studies on transfer students in spite of the increasing population of students; (2) The current research has mostly focused on transfer students' adjustment, retention, and graduation rate while relatively ignoring intellectual or academic growth or development of this population; (3) Studies often consider transfer students as a homogeneous group included with the non-transfer population.

\section{Cognitive Skills Development}

Cognitive development is often described as the higher order intellectual skills an individual gains from partaking in the academic experience (Kugelmass \& Ready, 2011). Helber, Zook, and Immergut (2012) use the term executive function to define the "complex, cognitive 
abilities necessary for planning, self-monitoring, goal setting, and strategic behavior" (p. 351). Pascarella and Terenzini (2005) define cognitive outcomes as the "utilization of higher-order intellectual processes such as knowledge acquisition, decision making, application, and reasoning" (p. 6). Regardless of the specific terminology used to describe cognitive development, research shows that the concept of cognitive development is relevant to all students regardless of race or gender. Essentially, gaining cognitive skills indicates that an individual may communicate more effectively, reason objectively, critically evaluate claims, and "make reasonable decisions in the face of imperfect information" (Pascarella \& Terenzini, 1991, p. 155). Cognitive development is the major goal of any academic experience.

\subsection{College Attendance and Cognitive Skills Development}

The current research on cognitive development is limited, as previously noted by Pascarella and Terenzini (1995) in their comprehensive examination of the literature. The few studies that do exist focus on cognitive gains apply to specific disciplines or to a single institution (Corbett, Kauffman, Maclaren, Wagner, Jones, 2010; Fortuin, van Koppen, \& Kroeze, 2013; Lampert, 2006). These studies may only be applicable to the student population at a particular campus or within a specific discipline. The results may not be transferrable across all institutions and departments. Despite the narrow focus of the studies, the results indicate that attending college leads to increased gains in cognitive development.

Kugelmass and Ready (2011) reported cognitive development gains between different racial/ethnic groups. The sample size included 35,000 students across 250 institutions. Results of the study showed that Hispanics perform at lower academic levels than White students at the beginning and end of college do. Yet, the rate at which Hispanics learn is comparable to their demographically similar White counterparts. Like Hispanic students, the initial academic disparities between White students and their African-American counterparts are reported at the beginning of college; however, the gap continues to widen further toward the end of college. Although not the focus of this study, results showed that students who transfer colleges make slightly smaller gains than non-transfer students in cognitive development. Additionally, the study also reported females make somewhat larger gains in academic achievement than males, after controlling for the other student-level characteristics. Although Kugelmass and Ready study included data on racial groups, gender, and transfer status, gender and race were not specifically selected for the transfer population.

Additional research conducted by Zhang and Watkins (2001) focused on the relationship between engagement in extracurricular activities and cognitive development. Such activities as work, travel, and leadership opportunities give participants a chance to encounter cognitive dissonance or psychological conflict, which ultimately creates learning or development. When students were challenged when working or having leadership responsibilities,

they had more opportunities to deal with different people, to cope with a wider range of problems, and to be exposed to diverse views. These exposures, it is suggested, would have provided students with better opportunities to be challenged to reason at a higher level of thinking (p. 254). 
In other words, encountering situations that create cognitive dissonance leads to cognitive development or intellectual growth. The sample population for this study was both American and Chinese students. This result applied to each of the groups. As with other research on cognitive development, the Zhang and Watkins study was restricted to a homogenous group of American students and did not account for differences in non-transfer versus transfer populations.

\subsection{Predictors of Cognitive Skills Development}

Traditionally, the literature on student gains in college focuses on student persistence or success defined by course completion or graduation. Non-cognitive predictors, such as high school grade point average (GPA) and standardized test scores, often predict college persistence and student success (Lax, 2012). However, the value of receiving a college education should be expanded beyond completion.

Previous research has identified both in- and out-of-class activities that contribute to cognitive development. Studies that focus on teaching practices indicate that faculty-student, non-classroom interaction and specific class assignments both directly affect college students' ability to develop critical thinking skills (Pascarella and Terenzini, 2005; Shim \& Walczak, 2012). Additionally, Shim and Walczak (2012), also found that engaging in challenging questions increases students self-reported and directly measured critical thinking skills. Furthermore, interpreting abstract concepts and giving well-organized presentations increases self-reported gains, but has no significant effect on critically thinking skills demonstrated by standardized assessment instruments (Astin, 1993; Shim \& Walczak, 2012).

According to Pascarella and Terenzini (2005), social engagement and co-curricular activities also reinforced cognitive development during the college years.

Interactions with peers that extend and reinforce broad ideas introduced in one's academic experience and that confront the individual with diverse interests, values, political beliefs, and cultural norms appear the most salient in positive impact on critical thinking, analytical skills, and post formal reasoning (p. 208).

Engagement in club and organizations also promoted critical thinking. However, the literature supporting this claim is less prevalent than the evidence supporting the correlation between peer interaction and critical thinking (Pascarella and Terenzini, 2005). The typical transfer student may find engaging in informal and formal social organizations challenging because they may they feel "out of place or older than other students" (Britt \& Hirt, 1999, p. 199).

\section{Experiences and Outcomes of Transfer Students}

Transfer students struggle with issues that compound the transition process from one institution to another. Often transfer students experience a decline in grades after transferring to a new institution. Laanan (2001) identifies this phenomenon as "transfer shock". Research suggests that this decline may be explained by the increase in difficulty of a concentrated major (Britt \& Hirt, 1999). Furthermore, Britt and Hirt (1999) reveal additional social and psychological struggles that are unique to transfer students. Many transfer students report 
"feeling out of place or older than other student" (p. 199). In other words, these struggles may contribute to the social isolation experienced by transfer students.

Based on the above findings, transfer students may need more services than traditional students to ease the transfer process. Colleges and universities that have positive transfer policies are associated with having higher levels of transfer student success (Pascarella \& Terenzini, 2005).

Research indicates that transfer students have unique needs (Tobolowsky \& Cox, 2012). Perhaps, identifying the factors that lead to cognitive development amongst transfer students can enhance the direction of policy development and reinforcement of environmental factors for college administrators, faculty, and staff. This research study will attempt to identify course and research engagement factors that contribute to cognitive development amongst transfer students by gender and race.

\section{Purpose of the Study}

The purpose of the study is to improve the understanding of transfer college students, by examining the patterns in and predictors of cognitive skills development among transfer college students. Moreover, this study also examines how such patterns and predictors differ by student's gender and race within this population. Set within the context of a statewide research university system, we seek to answer the following three research questions: (1) are the patterns in cognitive skills development among transfer students different depending on students' gender and race? (2) What college experiences contribute to cognitive skills development among transfer students? (3) How do the college experiences contributing to cognitive skills development among transfer students differ by student gender and race?

\section{Method}

\subsection{Data Source and Sample}

This study utilized the 2010 University of California Undergraduate Experience Survey (UCUES), a biannual statewide survey administered to all undergraduate students on nine University of California (UC) campuses. The survey is administered by the Office of Student Research at the University of California Berkeley, and is managed by the Office of the President for the University of California.

Given that this study measuring actual "development" or "growth" in cognitive skills among transfer college students after they were fully exposed to actual college experiences, the study sample was limited to senior undergraduate transfer students $(n=6,571)$. The final analytical sample of this study was primarily female students (57\%), first-generation students (59\%), and middle class or above $(51 \%)$. The ethnic composition of the sample consisted of a majority of White (45\%) students and Asian (32\%) students, with a smaller sample of Latino (20\%) and African-American (3\%) students. Due to the sample being limited to college seniors, the age distribution of the sample was primarily in the two categories between $20-21(33 \%)$ and $22-29(52 \%)$. 


\subsection{Variables}

The dependent variable of the study was college students' cognitive skills in their senior year, which were developed in previous research (Kim, Edens, Iorio, Curtis, \& Romero, 2014). To measure the cognitive skills, a factor scale was developed (Post-test $\alpha=.85$, Pre-test $\alpha=.84$ ) that consisted of five items assessing students' self-rating during their senior college year on their ability to (1) think analytically and critically, (2) write clearly and effectively, (3) read and comprehend academic material, (4) speak clearly and effectively in English, and (5) understand a specific field of study within their major (Table 1).

Table 1. Factor Loadings and Reliability for Cognitive Skills Development Scales

\begin{tabular}{|c|l|l|}
\hline Factors and Survey Items & $\begin{array}{l}\text { Factor } \\
\text { Loading }\end{array}$ & $\begin{array}{l}\text { Internal } \\
\text { Consistency }(\alpha)\end{array}$ \\
\hline \hline Cognitive Skills Development Scale & .85 \\
\hline Current proficiency: analytical and critical thinking skills & .84 & \\
\hline Current proficiency: ability to write clearly and effectively & .81 & \\
\hline Current proficiency: read and comprehend academic material & .83 & \\
\hline Current proficiency: ability to speak clearly and effectively in English & .73 & \\
\hline Current proficiency: understanding of a specific field of study major & .73 & \\
\hline Cognitive Skills Pretest & & .84 \\
\hline Started UC proficiency: analytical and critical thinking skills & .84 & \\
\hline Started UC proficiency: ability to write clearly and effectively & .85 & \\
\hline Started UC proficiency: read and comprehend academic material & .84 & \\
\hline $\begin{array}{l}\text { Started UC proficiency: ability to speak clearly and effectively in } \\
\text { English }\end{array}$ & .69 & \\
\hline Started UC proficiency: understanding of a specific field of study & .68 & \\
\hline
\end{tabular}

Following Astin's I-E-O model (1993), independent variables of this study were organized in sequential order as follows: (1) pre-college cognitive skills, (2) student demographics and academic preparedness, (3) declared majors, and (4) college experience items. Pre-college cognitive skills were measured by a four-time factor representing students' self-assessment of their cognitive skills when they entered college in the same four areas as the dependent variable, excluding the item assessing major field of study. Student demographics and academic preparedness included student gender, race, first-generation status, social class, and high school GPA. Declared majors were divided into five categories: (1) Social Sciences, (2) STEM (science, technology, engineering, and math), (3) Professional, (4) Humanities, and (5) other.

As this study is focused on the experiences that lead to cognitive development for transfer students, another set of independent variables was selected to reflect those experiences. College experiences included a broad range of variables thought to be associated with students' cognitive skills development, such as research engagement with faculty, satisfaction 
with major, satisfaction with advising, course engagement, and extracurricular engagement.

\subsection{Analysis}

After cleaning and screening the dataset based on recommendations from Tabachnick and Fidell (2007), a missing values analysis (MVA) was conducted. Data was determined to be missing at random (MAR) and all missing data was imputed using the Expectation-Maximization (EM) algorithm as recommended by Tabachnick and Fidell (2007). All data screening and analyses was conducted utilizing IBM SPSS Statistics version 20.0.

To analyze the data, multiple sets of independent samples t-tests were conducted to examine the differences in cognitive skills scores (for both pre- and post-test measures) depending on students' gender and race within transfer college students. Second, a series of hierarchical multiple regression analyses were used to identify the predictors of cognitive skills development among transfer college students and examine how the predictors differ across gender and race subgroups within this population.

\section{Results}

\subsection{Differences in Cognitive Skills Scores by Gender and Race within Transfer College Students}

Results from independent samples t-test show that there are significant differences in both pre-test and post-test cognitive skills scores across transfer students' gender and race subgroups (see Tables 2 and 3). In terms of gender differences, female transfer college students tended to report higher cognitive skills scores than their male peers when they entered college, while male transfer college students tended to report higher cognitive skills scores than their female counterparts during senior college year. When evaluating racial differences, White transfer college students tended to report higher cognitive skills scores than their non-White counterparts both when they entered college and in their senior year of college. All $t$-test scores were significant at the $p<.001$ level.

Table 2. Cognitive Skills Scores by Gender within Transfer College Students

\begin{tabular}{|l|c|c|c|c|}
\hline \multirow{2}{*}{} & \multicolumn{2}{|c|}{ Cognitive Skills } & \multicolumn{2}{c|}{ Cognitive Skills } \\
\cline { 2 - 5 } & \multicolumn{2}{|c|}{ Pre-Test } & \multicolumn{2}{c|}{ Post-Test } \\
\cline { 2 - 5 } & Mean & SD & Mean & SD \\
\hline Male & 1.98 & 0.78 & 2.01 & 0.74 \\
\hline Female & 2.04 & 0.78 & 1.98 & 0.74 \\
\hline
\end{tabular}

Note: Sample size varies: Pre-Test: Male $N=2,466$, Female $N=2,876$. Post-Test: Male $N=$ 2,420 , Female $N=2,843$. All independent samples $t$-tests results were statistically significant $(t$ ranges from -4.79 to $2.60, p<.001$ ).

Table 3. Cognitive Skills Scores by Race within Transfer College Students 


\begin{tabular}{|l|c|c|c|c|}
\hline \multirow{2}{*}{} & \multicolumn{2}{|c|}{ Cognitive Skills } & \multicolumn{2}{c|}{ Cognitive Skills } \\
\cline { 2 - 5 } & \multicolumn{2}{|c|}{ Pre-Test } & \multicolumn{2}{c|}{ Post-Test } \\
\cline { 2 - 5 } & Mean & SD & Mean & SD \\
\hline White & 2.20 & 0.74 & 2.18 & 0.69 \\
\hline African-American & 2.13 & 0.8 & 2.14 & 0.74 \\
\hline Asian & 1.76 & 0.73 & 1.67 & 0.71 \\
\hline Latino & 2.02 & 0.76 & 2.06 & 0.72 \\
\hline
\end{tabular}

Note: Sample size varies: Pre-Test: Not White $\mathrm{N}=2,605$, White $\mathrm{N}=2,245$. Post-Test: Not White $\mathrm{N}=2,548$, White $\mathrm{N}=2,231$. All independent samples t-tests results were statistically significant ( $\mathrm{t}$ ranges from -16.523 to $-.629, \mathrm{p}<.001$ ).

\subsection{Predictors of Cognitive Skills Development among Transfer College Students}

First, a hierarchical multiple regression analysis was performed to identify college experiences that significantly contribute to cognitive skills development among transfer college students, controlling for the confounding effects of student inputs and academic majors. The input variable of pre-test cognitive skills was used in the first step. The second step consisted on the demographic variables of first-generation status, social class, and high school GPA. The third step contained the academic majors. The final block contained the college experience variables of quality of instruction in major courses, satisfaction with access and availability of courses within the major, sense of belonging, satisfaction with advising, academic participation and interaction, research or creative projects experience, collaborative work, critical reasoning and assessment of reasoning, elevated academic effort, extracurricular engagement, poor academic habits, time employed, and academic time. The overall model was able to significantly predict $42 \%$ (adjusted $R^{2}=.42$ ) of the variation in cognitive skills development for transfer students, $F(21,1575)=55.60, p<.001$.

Table 4 presents the results of the regression analysis. Several college experiences are significantly correlated with transfer students' cognitive skills development. Quality of instruction in courses in the major $(\beta=.07)$, sense of belonging and satisfaction $(\beta=.08)$, academic preparation and interaction $(\beta=.22)$, critical reasoning and assessment of reasoning $(\beta=.09)$, elevated academic effort $(\beta=.10)$, and time employed $(\beta=.05)$ are all significant at the $p<.05$ level.

Table 4. Regression Equations Predicting Cognitive Skills Development in Transfer Students 


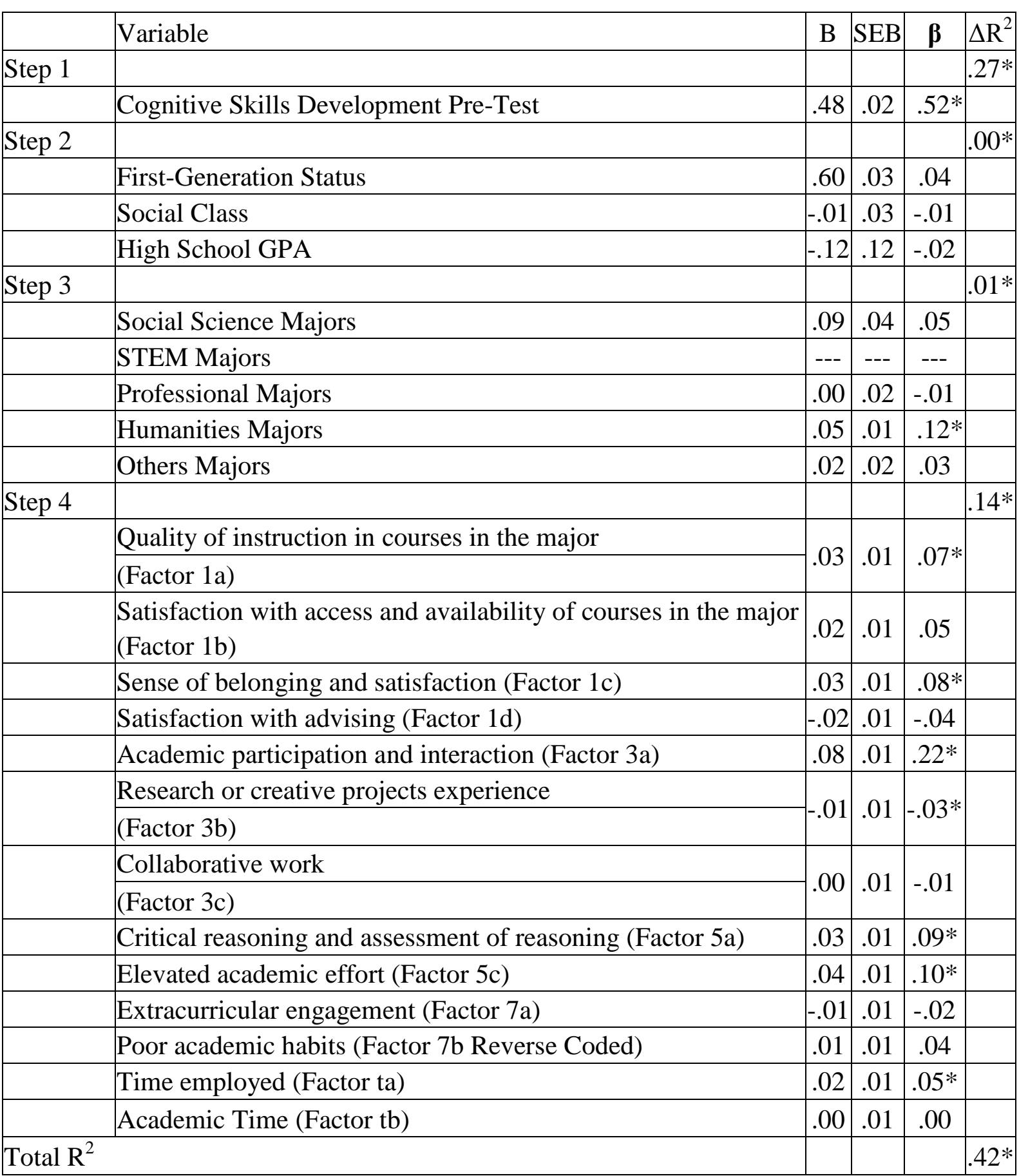

Note: $F(21,1575)=55.60, p<.001 ; *$ Were significant at the $p<.05$ level.

\subsection{Differences in Predictors of Cognitive Skills Development by Gender and Race within} Transfer College Students

\subsubsection{Gender differences}

Table 5. Regression Equations Predicting Cognitive Skills Development in Transfer Students 
by Gender

\begin{tabular}{|c|c|c|c|c|c|c|c|c|c|}
\hline & & \multicolumn{4}{|c|}{ Male } & \multicolumn{4}{|c|}{ Female } \\
\hline & Variable & $\mathrm{B}$ & SEB & $\boldsymbol{\beta}$ & $\Delta \mathrm{R}^{2}$ & $\mathrm{~B}$ & SEB & $\boldsymbol{\beta}$ & $\Delta \mathrm{R}^{2}$ \\
\hline \multirow[t]{2}{*}{ Step 1} & & & & & $.27 *$ & & & & $.26^{*}$ \\
\hline & Cognitive Skills Development Pre-Test & .49 & .03 & $.52 *$ & & .45 & .03 & $.51 *$ & \\
\hline \multirow[t]{3}{*}{ Step 2} & & & & & $.03 *$ & & & & $.03 *$ \\
\hline & First-Generation Status & .05 & .05 & .03 & & -.03 & .05 & -.02 & \\
\hline & Social Class & -.01 & .05 & -.01 & & -.01 & .05 & -.01 & \\
\hline \multirow[t]{6}{*}{ Step 3} & & & & & $.01 *$ & & & & $.00 *$ \\
\hline & Social Science Majors & -.10 & .06 & -.06 & & .05 & .07 & .03 & \\
\hline & STEM Majors & -.10 & .03 & -.13 & & --- & --- & --- & \\
\hline & Professional Majors & -.06 & .03 & .00 & & .00 & .02 & .00 & \\
\hline & Humanities Majors & --- & --- & --- & & .01 & .02 & .03 & \\
\hline & Others Majors & -.02 & .02 & -.03 & & .02 & .03 & .02 & \\
\hline \multirow[t]{3}{*}{ Step 4} & & & & & $.11 *$ & & & & $.15^{*}$ \\
\hline & Quality of instruction in courses in the major & \multirow{2}{*}{.02} & \multirow{2}{*}{.02} & \multirow{2}{*}{.04} & & \multirow{2}{*}{.02} & \multirow{2}{*}{.02} & \multirow{2}{*}{.06} & \\
\hline & (Factor 1a) & & & & & & & & \\
\hline & $\begin{array}{l}\text { Satisfaction with access and availability of } \\
\text { courses in the major (Factor 1b) }\end{array}$ & .03 & .02 & .06 & & .01 & .02 & .02 & \\
\hline & Sense of belonging and satisfaction (Factor 1c) & .03 & .01 & $.08^{*}$ & & .01 & .02 & .01 & \\
\hline & Satisfaction with advising (Factor 1d) & -.02 & .02 & -.04 & & -.01 & .02 & -.02 & \\
\hline & $\begin{array}{l}\text { Academic participation and interaction (Factor } \\
\text { 3a) }\end{array}$ & .06 & .01 & $.18^{*}$ & & .08 & .02 & $.23^{*}$ & \\
\hline & Research or creative projects experience & \multirow{2}{*}{.00} & \multirow{2}{*}{.01} & \multirow{2}{*}{.01} & & \multirow{2}{*}{-.04} & \multirow{2}{*}{.02} & \multirow{2}{*}{$-.09 *$} & \\
\hline & (Factor 3b) & & & & & & & & \\
\hline & Collaborative work & \multirow{2}{*}{-.01} & \multirow{2}{*}{.01} & \multirow{2}{*}{-.02} & & \multirow{2}{*}{.00} & \multirow{2}{*}{.01} & \multirow{2}{*}{.01} & \\
\hline & (Factor 3c) & & & & & & & & \\
\hline & $\begin{array}{l}\text { Critical reasoning and assessment of reasoning } \\
\text { (Factor 5a) }\end{array}$ & .02 & .01 & .06 & & .06 & .01 & .16 & \\
\hline & Elevated academic effort (Factor 5c) & .06 & .01 & .15 & & .03 & .01 & $.07 *$ & \\
\hline & Extracurricular engagement (Factor 7a) & .00 & .01 & $-.00 *$ & & -.01 & .01 & -.02 & \\
\hline & $\begin{array}{l}\text { Poor academic habits (Factor } 7 b \text { Reverse } \\
\text { Coded) }\end{array}$ & .00 & .01 & .01 & & .01 & .01 & .05 & \\
\hline & Time employed (Factor ta) & .03 & .01 & $.06 *$ & & .02 & .01 & .06 & \\
\hline & Academic Time (Factor tb) & -.01 & .01 & -.03 & & .03 & .01 & $.09 *$ & \\
\hline Total $\mathrm{R}^{2}$ & & & & & $.42 *$ & & & & $.44^{*}$ \\
\hline
\end{tabular}

Note: Males: $F(23,726)=24.54, p<.001$; Females: $F(23,549)=20.50 .=, p<.001$;

*Were significant at the $p<.05$ level.

Table 5 presents the results of separate regression analyses on cognitive skills development 
by student gender. Following the same stepwise progression as described above, the regression model using male transfer students was able to explain $42 \%$ of the variance in cognitive skills development $\left(F(23,726)=24.54, p<.001\right.$; adjusted $\left.R^{2}=.42\right)$. The model using female students was able to predict slightly more of the variance in cognitive skills development in this population $\left(F(23,549)=20.50, p<.001\right.$; adjusted $\left.R^{2}=.44\right)$. The significant positive predictors of cognitive skills development for male senior transfer students were: sense of belonging and satisfaction $(\beta=.08)$, academic participation and interaction $(\beta=.18)$, and time employed $(\beta=.06)$. For female senior transfer students, the significant positive predictors of cognitive skills development were: academic preparation ( $\beta$ $=.23)$, elevated academic effort $(\beta=.07)$, and academic time $(\beta=.09)$.

\subsubsection{Differences by Race}

A final regression was conducted to evaluate racial differences. The same blocks were created in the hierarchical regression model as described in the first equation. Table 6 presents the results of separate regression analyses on cognitive skills development by student race.

Table 6. Regression Equations Predicting Cognitive Skills Development in Transfer Students by Race

\begin{tabular}{|c|c|c|c|c|c|c|c|c|c|}
\hline & \multirow[b]{2}{*}{ Variable } & \multicolumn{4}{|c|}{ White } & \multicolumn{4}{|c|}{ Asian } \\
\hline & & $\mathrm{B}$ & SEB & $\boldsymbol{\beta}$ & $\Delta \mathrm{R}^{2}$ & $\mathrm{~B}$ & SEB & $\beta$ & $\Delta \mathrm{R}^{2}$ \\
\hline \multirow[t]{2}{*}{ Step 1} & & & & & $.29 *$ & & & & $.22 *$ \\
\hline & Cognitive Skills Development Pre-Test & .46 & .03 & .49 & & .40 & .02 & $.46 *$ & \\
\hline \multirow[t]{4}{*}{ Step 2} & & & & & $.01 *$ & & & & $.00 *$ \\
\hline & First-Generation Status & .07 & .04 & .05 & & .03 & .04 & .02 & \\
\hline & Social Class & .01 & .04 & .00 & & -.02 & .04 & -.01 & \\
\hline & Male & & & & & .16 & .06 & $.11 *$ & \\
\hline \multirow[t]{6}{*}{ Step 3} & & & & & $.01 *$ & & & & $.01 *$ \\
\hline & Social Science Majors & -.06 & .05 & -.04 & & .00 & .05 & -.01 & \\
\hline & STEM Majors & -.07 & .03 & $-.09 *$ & & -.02 & .03 & -.02 & \\
\hline & Professional Majors & -.06 & .02 & $-.09 *$ & & -.01 & .02 & -.02 & \\
\hline & Humanities Majors & --- & --- & --- & & --- & --- & --- & \\
\hline & Others Majors & -.02 & .02 & -.02 & & -.02 & .02 & -.03 & \\
\hline \multirow[t]{7}{*}{ Step 4} & & & & & $.13 *$ & & & & $.13 *$ \\
\hline & Quality of instruction in the major (Factor 1a) & .03 & .02 & .06 & & .04 & .01 & $.01 *$ & \\
\hline & $\begin{array}{l}\text { Satisfaction with access and availability of courses in } \\
\text { the major (Factor } 1 b \text { ) }\end{array}$ & .02 & .01 & .06 & & .10 & .01 & .04 & \\
\hline & Sense of belonging and satisfaction (Factor 1c) & .04 & .01 & $.10 *$ & & .02 & .01 & .06 & \\
\hline & Satisfaction with advising (Factor d) & -.02 & .01 & -.06 & & -.02 & .01 & -.05 & \\
\hline & Academic participation and interaction (Factor 3a) & .07 & .01 & $.19 *$ & & .06 & .01 & $.19 *$ & \\
\hline & Research or creative projects experience (Factor 3b) & .01 & .01 & .02 & & -.01 & .01 & -.02 & \\
\hline
\end{tabular}




\begin{tabular}{|l|l|c|c|c|c|c|c|c|c|}
\hline & Collaborative work (Factor 3c) & -.01 & .01 & -.02 & & -.01 & .01 & -.02 & \\
\hline & $\begin{array}{l}\text { Critical reasoning and assessment of reasoning (Factor } \\
\text { 5a) }\end{array}$ & .02 & .01 & 0.05 & & .03 & .01 & $.09 *$ & \\
\hline & Elevated academic effort (Factor 5c) & .06 & .01 & $.14 *$ & & .04 & .01 & $.12 *$ & \\
\hline & Extracurricular engagement (Factor 7a) & .01 & .01 & .01 & & -.01 & .01 & -.02 & \\
\hline & Poor academic habits (Factor 7b Reverse Coded) & .00 & .01 & .00 & & .01 & 0.01 & .04 & \\
\hline & Time employed (Factor ta) & .02 & .01 & $.05 *$ & & .02 & .01 & .05 & \\
\hline & Academic time (Factor tb) & -.02 & .01 & -.05 & & .02 & .01 & .04 & \\
\hline Total $\mathrm{R}^{2}$ & & & & & $.44 *$ & & & & $.36 *$ \\
\hline
\end{tabular}

Note: White: $F(20,841)=34.88, p<.001$; Asian: $F(21,935)=26.03, p<.001$;

$*$ Were significant at the $p<.05$ level

Table 6. continued

\begin{tabular}{|c|c|c|c|c|c|c|c|c|c|}
\hline & & \multicolumn{4}{|c|}{ Latino } & \multicolumn{4}{|c|}{ African-American } \\
\hline & Variable & $\mathrm{B}$ & SEB & $\boldsymbol{\beta}$ & $\Delta \mathrm{R}^{2}$ & $\mathrm{~B}$ & SEB & $\boldsymbol{\beta}$ & $\Delta \mathrm{R}^{2}$ \\
\hline \multirow[t]{2}{*}{ Step 1} & & & & & $21 *$ & & & & $.29 *$ \\
\hline & Cognitive Skills Development Pre-Test & .38 & .05 & $.44 *$ & & .74 & .26 & $.76^{*}$ & \\
\hline \multirow[t]{4}{*}{ Step 2} & & & & & $.00 *$ & & & & $-.09 *$ \\
\hline & First-Generation Status & -.02 & .09 & -.02 & & 1.34 & .57 & .99 & \\
\hline & Social Class & .00 & .08 & .00 & & -0.7 & .57 & -.51 & \\
\hline & Male & -.03 & .08 & -.02 & & .65 & .30 & .46 & \\
\hline \multirow[t]{6}{*}{ Step 3} & & & & & $.00 *$ & & & & $.15 *$ \\
\hline & Social Science Majors & .02 & .12 & .02 & & .39 & .54 & .21 & \\
\hline & STEM Majors & -.04 & .05 & -.05 & & .12 & .32 & .14 & \\
\hline & Professional Majors & .02 & .05 & .02 & & -.27 & .32 & -.23 & \\
\hline & Humanities Majors & --- & --- & --- & & --- & --- & --- & \\
\hline & Others Majors & -.08 & .04 & $-.12 *$ & & -.14 & .13 & -.33 & \\
\hline \multirow[t]{9}{*}{ Step 4} & & & & & $.12 *$ & & & & $.31 *$ \\
\hline & Quality of instruction in the major (Factor 1a) & .06 & .03 & .14 & & -.17 & .12 & -.41 & \\
\hline & $\begin{array}{l}\text { Satisfaction with access and availability of courses } \\
\text { in the major (Factor 1b) }\end{array}$ & .01 & .03 & .02 & & .33 & .29 & .82 & \\
\hline & Sense of belonging and satisfaction (Factor 1c) & .02 & .03 & .04 & & -.18 & .14 & -.39 & \\
\hline & Satisfaction with advising (Factor d) & -.04 & .03 & -.11 & & -.17 & .24 & -.44 & \\
\hline & Academic participation and interaction (Factor 3a) & .07 & .02 & $.21 *$ & & .22 & .13 & .69 & \\
\hline & Research or creative projects experience (Factor 3b) & .02 & .03 & .05 & & .19 & .13 & .53 & \\
\hline & Collaborative work (Factor 3c) & -.01 & .03 & -.03 & & -.37 & .18 & -.83 & \\
\hline & $\begin{array}{l}\text { Critical reasoning and assessment of reasoning } \\
\text { (Factor 5a) }\end{array}$ & .03 & .02 & .07 & & .16 & .11 & .39 & \\
\hline
\end{tabular}




\begin{tabular}{|l|l|c|c|c|c|c|c|c|c|}
\hline & Elevated academic effort (Factor 5c) & .04 & .02 & .11 & & .30 & .11 & $1.02 *$ & \\
\hline & Extracurricular engagement (Factor 7a) & .01 & .03 & .03 & & .04 & .13 & .11 & \\
\hline & Poor academic habits (Factor 7b Reverse Coded) & .01 & .01 & .04 & & -.08 & .15 & -.27 & \\
\hline & Time employed (Factor ta) & .01 & .02 & .03 & & -.19 & .12 & -.46 & \\
\hline & Academic time (Factor tb) & .03 & .02 & .07 & & .07 & .16 & .43 & \\
\hline Total $\mathrm{R}^{2}$ & & & & & $.33 *$ & & & & $.46 *$ \\
\hline
\end{tabular}

Note: White: $F(20,841)=34.88, p<.001$; Asian: $F(21,935)=26.03, p<.001$;

$*$ Were significant at the $p<.05$ level

The regression model predicting White transfer students' cognitive skills development was able to explain $44 \%$ of the variance of the dependent variable $(F(20,841)=34.88, p<.001)$. The significant predictors for White transfer students include majoring in STEM $(\beta=-.09)$ or Professional $(\beta=-.09)$ fields, sense of belonging $(\beta=.10)$, academic participation and interaction $(\beta=.19)$, elevated academic effort $(\beta=.14)$, and time employed $(\beta=.05)$. The model using Asian transfer students was able to explain $36 \%$ of the variance in the cognitive development $(F(21,935)=26.03, p<.001)$. The significant predictors for this population were: being male $(\beta=.16)$, satisfaction with quality of instruction $(\beta=.01)$, academic participation and interaction $(\beta=.19)$, critical reasoning and assessment of reasoning $(\beta$ $=.09)$, and elevated academic effort $(\beta=.12)$. The third model predicting the cognitive development of Latino students was able to explain $33 \%$ of the variance in the dependent variable $(F(21,215)=6.49, p<.001)$, with the significant predictors being Other Majors $(\beta=$ -.12), and academic participation and interaction $(\beta=.21)$. Lastly, the model on African-American transfer students was able to explain $46 \%$ of the variance $(F(4,21)=2.01$, $p<.001)$ and had a single significant predictor of elevated academic effort $(\beta=1.02)$.

\section{Discussion and Implications}

Findings from this study show that cognitive development occurs differently for various student subgroups within the transfer student population. The first goal of this study was to investigate the differences in cognitive development of transfer students by race and gender.

When analyzed by gender, only male transfer students reported actual gains in cognitive skills while in college. A gender discrepancy in the cognitive development gains between males and females has previously been identified in the literature (Carnevale, Smith, Gulish, \& Beach, 2012). In this study, the amount of difference for both males and females is relatively small. The smaller difference may relate to the fact that two-thirds of student cognitive development occurs within the first two years of college (Pascarella \& Terenzini, 2005). The students are self-reporting and estimating their gains in college at a point in their senior year. Much of their perceived cognitive development may have occurred during their attendance at community college. Further evidence of the impact of the first two years exists in the literature. Focused on the nursing student group, a population that is mainly female in composition, Facione (1997) reported that 63 percent of significant critical thinking development occurs in the second year 
of college. Facione's findings may be applicable to the female student transfer population. Possibly, female transfer students developed their greatest gains in cognitive development in their second year, occurring before the completion of the pre-test survey. Therefore, the significant gains in cognitive development for the female student population may have occurred before transfer. Additional research studies that measure cognitive skills during three different points in time (upon entry into college, at the point of transfer, and in senior year) could offer greater explanation to this gender discrepancy.

Understanding that much of the gains in cognitive development occur during the first two years, there are implications for both community college administrators and 4-year college and university administrators. For community colleges, there needs to be a continued focus on the development of the student while attending. Students that will be transferring, as well as students attending for other reasons, need classroom experiences and extracurricular activities that support cognitive development. Once the student has transferred, 4-year colleges must focus on integrating the student into the campus environment and providing strong programs and support within the transfer student's field of study.

Ethnicity is another lens for evaluating differences in cognitive development. The cognitive development scores reported at the time students transferred into college and during their senior year were highest among the Caucasian student population compared to all other ethnic groups. However, African-American and Latino students showed gains in cognitive development whereas Caucasian and Asian students showed no gain from transfer year to senior year.

Again, these small gains identified for transfer students may be related just to fact that a majority of student development and learning occurs during the student's first two years (Pascarella \& Terenzini, 2005). Like the female student population, Caucasian and Asian transfer student populations did not show gains in cognitive development from their pre- to post cognitive test scores. Although the Caucasian group had the greatest mean scores (2.20 and 2.18, pre- and post, respectively), White students may have developed their significant cognitive gains prior to transfer. Another consideration is that approximately forty percent of all undergraduates begin their college career at a community college (Seidman, 2012). Perhaps, the greatest gains in cognitive development occurred during these community college years. This claim suggests that community colleges should continue offering opportunities that challenge and promote critical thinking during the early college experience. These challenging opportunities prepare the transfer for the academic environment at the 4-year schools.

Beyond differences in cognitive development, another goal of this study was to evaluate the predictors of transfer student cognitive development. Three themes emerged in the findings. First, the predictors for cognitive development during the undergraduate years differ between female and male transfer students. For female transfer students, the academic predictor variables (academic preparation, elevated academic effort, and academic time) were significant in explaining the variance in cognitive development. For the male transfer student population, both academic and satisfaction items (sense of belonging and satisfaction, academic participation and interaction, and time employed) significantly predicted the variance in cognitive development. The findings suggest that female specific programs 
should focus on academic items such as effort, research opportunities, and overall satisfaction with the academic experience. However, male specific programs may need to foster sense of belonging on campus in both extracurricular and academic settings.

The second theme that emerged from the data showed that African-American and Latino students benefited cognitively from their transfer experience. Contrary to the findings of Kugelmass and Ready (2011), Caucasian and Asian students did not report cognitive gains from their transfer year to their senior year. Perhaps, the results suggest that both majority groups either acquired their cognitive skills prior to transfer or their transfer experience negatively impacted their cognitive skills development. Further research is needed to explore the factors that contributed to this lack of cognitive development in the Caucasian and Asian student populations.

The last theme that emerged from the results indicated that Latino and African-American transfer students' academic experiences are positively correlated with their cognitive development. Latino students, in particular, reported academic participation and interaction and other majors as two factors that contributed significantly to their positive cognitive development. However, African-American transfer students benefited from academic effort. As a result, administrators and instructors serving Latino and African-American transfer students should offer opportunities for academic involvement and provide mechanisms for fostering engagement and study skills. White, Asian, Latino, and African-American students all have many similar predictors of cognitive development. For all racial groups, with exception of the African-American group, academic participation and interaction was a predictor of cognitive skills development. In addition, every racial group, except the Latino population, has elevated academic effort as a significant predictor. Again, administrations should create a strong, engaging, and challenging academic environment to foster the development of transfer students. These programs can coincide with those that are designed for traditional students, as both populations may benefit.

Studies indicate that institutions that emphasize curriculum and a student's quality of effort or involvement have a positive impact on student's cognitive development (Pascarella \& Terenzini, 2005). Corroborating the above findings, the results of this study indicate that two academic items (academic participation and interaction and elevated academic effort) are significant predictors of cognitive development for all ethnic groups except African-Americans and Latinos, respectively. Thus, course development that emphasizes active learning and reinforces student's academic efforts could lead to greater gains in cognitive development during the pre and post transfer experience.

The findings of the study also suggest several practical and theoretical implications. Important to administrators is the need to monitor students' level of satisfaction and provide programs that enhance satisfaction and sense of belonging on campus as well as increased opportunities to work with faculty. In addition, universities that collaborate with community colleges may ease the transfer process and promote further cognitive development after the transfer period. Clearly, this study indicates that different ethnic groups have similar and different factors that contribute to cognitive development. Creating programs that satisfy these overlapping factors and address individual needs by ethnicity may increase cognitive 
gains in the transfer student population.

\section{Limitations}

Although the study included a robust sample size, there were several limitations. First, the data relied on self-reported responses. Thus, the outcome was based on the perception of the respondent, not objective, cognitive development measures. However, self-reported measures have been noted as acceptable proxies for more direct measures of cognitive development and learning (Anaya, 1999). Secondly, the scope of the study was restricted to the public university system located in the Southwestern region of the United States, excluding other types of institutions. Third, the survey data did not detail the student transfer pattern, such as transfer from a two-year college to a four-year university or vice-versa. Identifying the transfer pattern may have helped to explain the difference in cognitive gains among the different racial groups.

Lastly, the year (first, second, third, or senior) that the student transferred from one institution to another was not included in the data collection, making it difficult to determine the initial level of cognitive development that the student may have gained from their earlier college experience. Determining this initial cognitive level may account for the differences in cognitive development between males and females. For example, the female group, who showed no significant gains from the initial reporting to their senior year, could be explained by early cognitive development gains that occurred before transfer. Males, on the contrary, could be delayed in their cognitive development, showing greater strides later in their college experience. Future studies could contribute to the exact cause of this discrepancy.

\section{Conclusions}

Previous studies examining cognitive skills development in college students support the findings of this study. Transfer students are a unique population of students that require specific programs and support to be successful in college. Men and women transfer students have differing predictors of cognitive development while in college. In addition, different factors affect the cognitive development of transfer students from various ethnicities. In general, transfer students need to be challenged academically, feel satisfied with their college experience, and believe as if they belong on their new campus.

We expect that findings from the study would assist college and university professionals in understanding transfer college students on their campuses and strategizing interventions to facilitate learning and development of this population. Additionally, much of the earlier research concerning transfer college students has utilized a single-institution or small sample size dataset. This study, however, utilized data collected at multiple institutions within a large, public university system. As a result, our findings based on data from multiple institutions provide additional knowledge in some areas that have already been explored at single institutions. Furthermore, this study add new insights to existing literature on transfer college students by examining how the patterns in and predictors of cognitive skills development differ by student's gender and race within this population.

\section{References}


Anaya, G. (1999). College impact on student learning: Comparing the use of self-reported gains, standardized test scores, and college grades. Research in Higher Education, 40, 499-526. http://dx.doi.org/10.1023/A:1018744326915

Astin, A. W. (1993). What matters in college: Four critical years revisited. San Francisco, CA: Jossey-Bass.

Britt, L. W., \& Hirt, J. B. (1999). Student experiences and institutional practices affecting spring semester transfer students. NASPA Journal, 36, 198-209. http://dx.doi.org/10.2202/ 0027-6014.1086

Carnevale, A. P., Smith, N., Gulish, A., \& Beach, B. H. (2012). Healthcare executive summary. Washington DC: Georgetown University Center on Education and the Workforce. Retrieved from http://files.eric.ed.gov/fulltext/ED533706.pdf

Cejda, B. D., Kaylor, A. J., \& Rewey, K. L. (1998). Transfer shock in an academic discipline: The relationship between students' major and their academic performance. Community College Review, 26, 1-13. http://dx.doi.org/10.1177/009155219802600301

Corbett, A., Kauffman, L., Maclaren, B., Wagner, A., \& Jones, E. (2010). A cognitive tutor for genetics problem solving: Learning gains and student modeling. Journal of Educational Computing Research, 42, 219-239. http://dx.doi.org/10.2190/EC.42.2.e

Davies, T. G., \& Dickmann, E. M. (1998). Can we hear them? Do we listen?: Student voices in the transfer process. Community College Journal of Research and Practice, 22, 541-557. http://dx.doi.org/10.1080/1066892980220507

Dundar, A., Hossler, D., Shapiro, D., Chen, J., Martin, S., \& Torres, V. (2011). National postsecondary enrollment trends: Before, during, and after the great recession. Signature[TM] Report 1. National Student Clearinghouse.

Eimers, M. T., \& Mullen, R. W. (1997). Transfer Students: Who are They and How Successful Are They? College and University, Winter, 9-19.

Facione, P. (1997). Critical thinking assessment in nursing education programs: An aggregate data analysis. Millbrae, CA: California Academic Press.

Fortuin, K. J., van Koppen, C. A., \& Kroeze, C. C. (2013). The Contribution of systems analysis to training students in cognitive interdisciplinary skills in environmental science education. Journal of Environmental Studies and Sciences, 3, 139-152. http://dx.doi.org/10. 1007/s13412-013-0106-3

Helber, C., Zook, N., \& Immergut, M. (2012). Meditation in higher education: Does it enhance cognition?. Innovative Higher Education, 37(5), 349-358. http://dx.doi.org/10.1007/ s10755-012-9217-0

Hossler, D., Shapiro, D., Dundar, A., Chen, J., Zerquera, D., \& Ziskin, M. (2012). Reverse transfer: A national view of student mobility from four-year to two-year institutions. Signature [TM] Report 3. National Student Clearinghouse. 
Hossler, D., Shapiro, D., Dundar, A., Ziskin, M., Chen, J., Zerquera, D., \& Torres, V. (2012). Transfer and Mobility: A National View of Pre-Degree Student Movement in Postsecondary Institutions. Signature Report 2. National Student Clearinghouse. Retrieved from ERIC Database. (ED536121).

Hossler, D., Shapiro, D., Dundar, A., Ziskin, M., Chen, J., Zerquera, D., \& Torres, V. (2012). Transfer and mobility: A national view of pre degree student movement in postsecondary institutions. Signature [TM] Report 2. National Student Clearinghouse.

Kim, Y. K., Edens, D., Iorio, M., Curtis, C., \& Romero, E. (2014). Cognitive skills development among international undergraduate students at research universities in the United States. Paper presented at the Annual Meeting of the American Educational Research Association, Philadelphia, PA.

Kugelmass, H., \& Ready, D. D. (2011). Racial/ethnic disparities in collegiate cognitive gains: A multilevel analysis of institutional influences on learning and its equitable distribution. Research in Higher Education, 52, 323-348. http://dx.doi.org/10.1007/s11162-010-9200-5

Laanan, F. S. (2001). Transfer student adjustment. New Directions for Community Colleges, 2001(114), 5-13. http://dx.doi.org/10.1002/cc.16

Lampert, N. (2006). Critical thinking dispositions as an outcome of art education. Studies in Art Education: A Journal of Issues and Research in Art Education, 47, 215-228.

Lax, J. (2012). CUNY Community college graduation rates do not effectively measure student success. Thought \& Action, 28, 119-125.

Marling, J. L. (2013). Navigating the new normal: Transfer trends, issues, and recommendations. New Directions for Higher Education, 162, 77-87. http://dx.doi.org/10.1002/he.20059

Miville, M. L., \& Sedlacek, W. E. (1995). Transfer students and freshmen: Different or parallel experiences? NASPA Journal, 32, 145-152.

National Center for Education Statistics. (2013). Total fall enrollment in degree-granting institutions, by attendance status, sex, and age: Selected years, 1970 through 2021 . Retrieved December 29, 2014, from http://nces.ed.gov/programs/digest/d12/tables/dt12_224.asp

Pascarella, E., \& Terenzini, P. (1991). How college affects students: Findings and insights from twenty years of research. San Francisco: Jossey-Bass.

Pascarella, E., \& Terenzini, P. (2005). How college affects students: A third decade of research. San Francisco: Jossey-Bass.

Research and Planning Group for California Community Colleges. (2010). Transfer velocity project: Key findings on student transfer in California community colleges. Research and Planning Group for California Community Colleges.

Sanchez, J. R., Laanan, F. S., \& Wiseley, W. C. (1999). Postcollege earnings of former students of California community colleges: Methods, analysis, and implications. Research in Higher Education, 40, 87-113. http://dx.doi.org/10.1023/A:1018726428306 


\section{Macrothink}

Seidman, A. (2012). College student retention: Formula for student success (2nd ed.). Lanham, MD: Rowman \& Littlefield Publishers, Inc.

Seurkamp, M. P. (2007, October). Changing student demographics. Retrieved September 13, 2013, from http://www.universitybusiness.com/article/changing-student-demographics

Shim, W., \& Walczak, K. (2012). The impact of faculty teaching practices on the development of students' critical thinking skills. International Journal of Teaching and Learning in Higher Education, 24(1), 16-30.

Svinicki, M. (2004). Learning and motivation in the postsecondary classroom. Bolton, MA: Anker Publishing.

Tabachnick, B. G., \& Fidell, L. S. (2007). Using multivariate statistics (5th ed.). Boston: Allyn and Bacon.

Tobolowsky, B. F., \& Cox, B. E. (2012). Rationalizing neglect: An institutional response to transfer students. Journal of Higher Education, 83, 389-410. http://dx.doi.org/10.1353/jhe. 2012.0021

Zhang, L. \& Watkins, D. (2001). Cognitive development and student approaches to learning: An investigation of Perry's theory with Chinese and U.S. university students. Higher Education, 41, 239-261. http://dx.doi.org/10.1023/A:1004151226395

\section{Copyright Disclaimer}

Copyright reserved by the author(s).

This article is an open-access article distributed under the terms and conditions of the Creative Commons Attribution license (http://creativecommons.org/licenses/by/3.0/). 